\title{
Downs syndrom: God kommunikasjon fra helsepersonellet minsker foreldrenes påkjenning
}

Foreldre som uventet får et barn med Downs syndrom, kan få bedre samspill med barnet når helsepersonellet snakker til dem på en positiv måte rett etter fødselen.

\section{Forfattere}

\section{Anette Walle}

Tverrfaglig spesialist

Tildelingsenheten, Sørum kommune

\section{Lilliana Del Busso}

Professor

Avdeling for helse- og sosialfag, Høgskolen i Østfold, Halden

\section{Nøkkelord}

Downs Syndrom Foreldre Kommunikasjon Narrativ metode

Sykepleien Forskning 2018 13(70315)(e-70315)

DOI: https://doi.org/10.4220/Sykepleienf.2018.70315

\section{SAMMENDRAG}

Bakgrunn: Foreldre som mottar budskapet om at deres barn har Downs syndrom på sykehuset etter fødselen, kan oppleve det som en alvorlig og belastende livserfaring. Foreldrenes opplevelse av kommunikasjonen med helsepersonellet kan derfor være viktig for foreldrene for å håndtere følelsesmessige reaksjoner i tiden etter fødselen, og kan bidra til samspillet som skapes mellom foreldre og barn. 
Hensikt: Hensikten med artikkelen er å formidle kunnskap om hvordan foreldre til barn med Downs syndrom opplevde kommunikasjonen med helsepersonellet på sykehuset i tiden etter fødselen. Vi ønsker dessuten å vise hvilken betydning slik kommunikasjon kan ha for foreldrene for å mestre egne reaksjoner.

Metode: Studien har et kvalitativt design med en fenomenologisk og narrativ tilnærming. Vi gjennomførte narrative dybdeintervjuer med åtte biologiske foreldre til barn med Downs syndrom i alderen to til ti år. Ingen av foreldrene var kjent med at barnet hadde Downs syndrom $f ø r f ø d s e l e n$. Innsamlede data ble analysert ved hjelp av en narrativ analysemetode.

Resultat: Gjennom hovednarrativet «å ikke bli sett som et helt menneske» fortalte foreldrene om opplevelsen av å bli forlatt, utestengt fra kommunikasjon, henvist til en pc for å få informasjon om diagnosen til barnet og snakket til av helsepersonellet på en måte som de opplevde som belastende. I kontrast til dette fortalte foreldrene gjennom narrativet «å være et medmenneske» om konkrete situasjoner der helsepersonellets væremåte bidro til at de følte at både dem selv og barnet var i en relasjon til helsepersonellet som medmennesker.

Konklusjon: Studien indikerer at det har stor følelsesmessige betydning i tiden etter fødselen hvordan foreldrene opplever kommunikasjonen med helsepersonellet. Studien antyder også at foreldrene har behov for en kommunikasjonsmåte der de føler at barnet og deres egne reaksjoner blir ivaretatt og anerkjent.

Internasjonal forskning har antydet at barn med Downs syndrom, i likhet med barn med andre funksjonsnedsettelser, har en høyere risiko for å utvikle utrygg tilknytning og oppleve omsorgssvikt enn funksjonsfriske barn (1, 2). Denne risikoen relateres til barnets økte omsorgsbehov og foreldrenes emosjonelle ressurser og evne til å akseptere og respondere på barnets behov (1). I motsetning til denne forskningen fremkommer det i en NOVA-rapport fra 2011 at barn med funksjonsnedsettelser ikke er overrepresentert i barnevernet i Norge (3).

Lewis (4) foreslår imidlertid at øyeblikket da foreldrene blir fortalt at deres barn har en funksjonsnedsettelse, er et kritisk tidspunkt i den langsiktige utviklingen av samspillet mellom foreldre og barn. For foreldre kan denne beskjeden oppleves som en sterk følelsesmessig belastning. Foreldrenes opplevelse av sjokk, sorg og sinne kan være relatert til bekymring for barnets fremtid, barnets helseutfordringer og stigma relatert til barnets «annerledeshet» (5-9). 


\section{三 «Øyeblikket da foreldrene blir fortalt at deres barn har en funksjonsnedsettelse, er et kritisk tidspunkt i den langsiktige utviklingen av samspillet mellom foreldre og barn.»}

Få studier, både nasjonalt og internasjonalt, har undersøkt foreldres egne levde erfaringer i møte med helsepersonell på sykehuset i den kritiske tiden etter at de har fått et barn med Downs syndrom. Studien som presenteres i denne artikkelen, bidrar med å belyse foreldres egne konkrete levde erfaringer når det gjelder kommunikasjon med helsepersonell. I så måte synliggjør foreldrenes fortellinger helsepersonellets sentrale rolle og potensial når det gjelder deres følelsesmessige behov og samspill med barnet i denne tidlige fasen av foreldreskapet.

\section{Metode}

Studien har et kvalitativt design med en fenomenologisk og narrativ tilnærming. Fenomenologi kan forstås som vitenskapen om opplevelse slik den føles av subjektet, altså «hvordan det er» å ha en opplevelse (10-12). I kroppsfenomenologien er det «levd erfaring» og det som er følt og sanset i relasjon til andre og i det materielle rommet, som blir vektlagt $\mathrm{i}$ forsøket på å forstå opplevelse $(11,12)$.

Begrepet «narrativ» kan oversettes til «fortelling» (13). En fenomenologisk basert narrativ tilnærming kan egne seg spesielt godt til å fremskaffe rike detaljer om konkrete, gjennomlevde erfaringer av et fenomen. Denne tilnærmingen tilrettelegger for at deltakerne kan konstruere en fortelling hvor ulike erfaringer gis mening og settes i sammenheng.

\section{Utvalg}


Vi intervjuet åtte biologiske foreldre til barn med Downs syndrom i alderen to til ti år. Seks intervjuer ble gjort med mødre, ett intervju med en far, og i ett intervju var både moren og faren til stede. Vi gjennomførte intervjuene i 2014. Barna var født på ulike sykehus, og ingen av foreldrene var kjent med at barnet hadde Downs syndrom før fødselen. På sykehuset varierte tidspunktet for når budskapet ble overlevert, fra mindre enn seks timer (fire barn), mellom seks og tretten timer (ett barn), og til mer enn tretten timer (to barn) etter fødselen.

Deltakerne i studien ble rekruttert ved at vi utformet og sendte skriftlig forespørsel om å delta til Norsk Nettverk for Down Syndrom og Ups \& Downsforeninger i Norge, som distribuerte forespørselen videre via e-post og Facebook. De personene som på bakgrunn av denne forespørselen var interesserte i å delta i studien, kontaktet forskeren (førsteforfatteren) på telefon eller e-post.

\section{Narrativt intervju}

Vi utformet en intervjuguide etter hensikten med studien og på bakgrunn av den eksisterende litteraturen. Ved hjelp av guiden tilrettela forskeren (førsteforfatteren) for at foreldrene kunne fortelle ut fra egne konkrete gjennomlevde erfaringer heller enn å be dem snakke om det å ha et barn med Downs syndrom i mer generelle vendinger (12).

Foreldrene fikk muligheten til både å dele tanker og oppfatninger om sin opplevelse, og i større grad minnes og reflektere over det som var følt og sanset i spesifikke hendelser i møte med helsepersonellet («hvordan det var å ha opplevelsen») (11, 12). Videre kunne de flette de ulike opplevelsene inn i en lengre fortelling. Intervjuene varierte fra 1,5 til 2 timer i lengde.

\section{Narrativ analysemetode}


Intervjuene ble transkribert ordrett og analysert ved hjelp av en narrativ analysemetode. Analyseprosessen besto av seks overlappende analytiske steg utviklet av Del Busso (13), basert på Langdridges anbefalinger for kritisk narrativ analyse (14). I første steg av analysen foretok vi en grundig gjennomlesing av alle intervjuene. Vi reflekterte kritisk over inntrykk, umiddelbare tolkninger, ideer og tanker rundt materialet som helhet, og hva disse var begrunnet i (14).

I neste steg identifiserte vi beskrivelser av konkrete levde erfaringer. Disse beskrivelsene ble analysert i henhold til detaljene i beskrivelsen, for eksempel hvilke elementer som ble vektlagt av deltakeren, og hva slags mening deltakeren la i det som ble beskrevet (13). I det tredje steget av analysen kodet vi hvert av de transkriberte intervjuene for meningsbærende enheter. Enhetene ble deretter syntetisert i temaer. Så identifiserte vi temaene som gikk igjen på tvers av deltakerne.

Med temaene som utgangspunkt gikk neste steg ut på å identifisere fortellinger i hvert av intervjutranskriptene. De fortellingene som gikk igjen på tvers av deltakerne, ble så identifisert, og dannet to hovednarrativer. Det neste steget i analysen innebar å identifisere hvordan deltakerne «konstruerte seg selv» i narrativene. Deretter skulle vi se disse narrativene i lys av den eksisterende forskningslitteraturen om funksjonsnedsettelse.

\section{Etikk}

Studien ble meldt til og godkjent av Norsk samfunnsvitenskapelig datatjeneste (NSD) i 2013 (godkjenningsnr. 36355). Vi innhentet informert, skriftlig samtykke og informerte deltakerne om deres rett til å trekke seg fra studien når som helst i prosessen uten å måtte begrunne det. Alle identifiserende opplysninger ble anonymisert, og vi ga hver deltaker et pseudonym som brukes når vi publiserer funn fra studien. 
Vi benyttet forskerrefleksivitet som et metodologisk verktøy i alle forskningens faser for å påse en etisk, rettferdig og pålitelig forskningsprosess (15). Metoden gikk ut på å kritisk vurdere de aspektene ved forskeren og forskningsprosessen som bidro til dataene som ble produsert, og tolkningen av dette datamaterialet.

\section{Resultater}

I sine fortellinger om konkrete opplevelser i møte med helsepersonell på sykehuset $\mathrm{i}$ tiden etter fødselen formulerte de to fedrene og seks mødrene som deltok i studien, to kontrasterende hovednarrativer eller hovedfortellinger:

- «å ikke bli sett som et 'helt menneske'», og

- «å være et medmenneske».

\section{Å ikke bli sett som et «helt menneske»}

De fleste deltakerne i studien hadde hatt flere vanskelige opplevelser i møte med ulike ansatte innenfor helsevesenet da barnet deres ble født og i tiden umiddelbart etterpå. Mange hadde opplevd å bli ekskludert og forlatt. For eksempel hadde de opplevd at deres meninger ikke ble etterspurt og hørt, og at helsepersonellet var uforberedt på situasjonen. Det foreldre fortalte om disse erfaringene, var at de ikke opplevde å bli sett som et helt menneske av helsepersonellet de møtte.

Kari, mor til en liten jente, fortalt om en hendelse der hun opplevde at hun ble forlatt av jordmoren rett etter fødselen:

«Jordmor liksom bare forsvant, hun ble borte, så husker jeg hun sendte en beskjed og meddelte gjennom en annen, at 'ta kontakt med meg om du trenger det'. Når jeg nå ser bilder av henne som nyfødt, så tenker jeg at hun må ha sett det, men så sa hun ikke noe.» 
I ettertid tenkte Kari at det var sannsynlig at jordmoren mistenkte at barnet deres hadde Downs syndrom, og at hun unngikk å fortelle dem det. Dersom jordmoren hadde sett at barnet til Kari hadde Downs syndrom, kan det at jordmoren «forsvant» og kommuniserte gjennom en tredje person tolkes av Kari som at jordmoren fraskrev seg ansvaret. Det kan også forstås som at Kari, som nettopp hadde fått et funksjonshemmet barn, selv ble gitt ansvaret for å be om hjelp og støtte.

\section{Ble oversett}

Også Lise, mor til en gutt, fortalte om en opplevelse der hun følte at sykepleierne på barselavdelingen snakket med hverandre om barnet, men unngikk å snakke med henne:

«Det var akkurat som de var uforberedte på hva de skulle si, og hvordan de skulle håndtere en slik situasjon. De var usikre, og hvisket og tisket.»

Lise fortalte at hun følte sykepleierne på barselavdelingen var usikre, og at de snakket lavmælt og hviskende til hverandre i stedet for å snakke med henne. Lise beskrev at det gjorde henne usikker. Hun følte seg oversett, og hun følte at sykepleierne ikke så hennes behov for å bli inkludert og snakket med. Både Kari og Lise beskrev opplevelser der de følte at de ikke ble behandlet som mennesker som fortjente og hadde krav på omsorg og støttende kommunikasjon.

\section{Nedlatende holdninger}

I motsetning til Kari og Lise, som opplevde at de ikke ble kommunisert med, hadde Ine, mor til en gutt, opplevd at kommunikasjonen fra helsepersonell var reduserende eller nedlatende. Ina beskrev opplevelsen av å bli såret av helsepersonellets måte å kommunisere på, og fortalte at hun i tiden etter fødselen ble holdt atskilt fra barnet sitt: 
«... jeg fikk ikke stelle eller involvere meg i noe, for det var synd på meg. For dette var mitt første barn, stakkars meg, og da kjente jeg at jeg ble så sint. Alle de andre fikk høre 'så nydelig han er', eller 'så søt hun er', mens alt jeg fikk høre var 'er det barnet ditt? Stakkars deg'.»

Ina fortalte at holdningene som de ansatte hadde overfor henne og sønnen på barselavdelingen, såret og provoserte henne. Hun beskrev opplevelsen av at de ansatte på barselavdelingen ikke så sønnen som et nyfødt barn, som det er vanlig å kommunisere om på en positiv måte, «så søt han er», men som et avvik fra normalen. I tillegg til hennes opplevelse av å bli redusert til en det var synd på, opplevde hun at barnet ikke ble behandlet som en «vanlig» baby, men som en byrde.

\section{三 «Alle de andre fikk høre 'så nydelig han er', eller 'så søt hun er', mens alt jeg fikk høre var 'er det barnet ditt? Stakkars deg'.»}

Ina, informant

Ina fortalte at for henne var det ikke noen stor sorg at sønnen hadde Downs syndrom. Hun forklarte det med at da hun fikk et barn med Downs syndrom, presset det frem endringer i livet hennes som hun tidligere hadde ønsket, men ikke klart å gjennomføre. Det ble derfor meningsfylt og positivt for Ina at nettopp hun ble mor til et barn med Downs syndrom. I Inas fortelling syntes hun at barnet var verdifullt og bidro til å styrke hennes handlingspotensial. Det kontrasterte med opplevelsen av at hun selv og barnet sitt ble sett på som «stakkarslige» og «avvikende» av de ansatte på barselavdelingen.

\section{Lite empati fra legen}


Mange av deltakerne hadde opplevd at informasjon ble formidlet på en lite sensitiv og empatisk måte, at de ikke fikk tilstrekkelig informasjon, og at informasjonen var mangelfull eller utdatert. Deltakerne beskrev disse opplevelsene som frustrerende og belastende.

Kari fortalte om en opplevelse da hun mottok informasjon fra en lege:

«Det kom en lege, en litt sånn rar lege, han pratet veldig teknisk: 'Ja det er noe med oksygenopptaket ... ', men han ga ikke noen ordentlig øyekontakt, og han sto liksom sånn [viser ved å snu hodet delvis bort og se i taket] og snakket litt ut i luften. 'Det er noe med oksygen, så vi har lagt henne i kuvøse.' Jeg husker jeg tenkte: 'Jeg blir gal, sånn er det å bli gal' [ler].»

I sitatet ovenfor fortalte Kari at hun syntes møtet med legen var vanskelig. Han var kun opptatt av å gi medisinsk informasjon, og ikke av å møte og se foreldrenes tilstand og behov. I denne sammenhengen hadde legen utelukkende en medisinsk tilnærming til å møte og gi informasjon til foreldrene. Han fokuserte på å identifisere barnets symptomer (lite oksygenopptak), og hvordan barnet kunne bli bedre (trenger behandling/kuvøse). Måten han kommuniserte på (teknisk, og snakket ut i luften) og hans væremåte (så ikke på foreldrene da han snakket), ga Kari en følelse av «å bli gal».

Ut fra Karis beskrivelse kan denne hendelsen tolkes som at legen hadde en væremåte som ikke tilrettela for at Kari kunne være et «helt» menneske i interaksjonen med ham. Eksempler på legens væremåte er at han ikke hadde øyekontakt og ikke imøtekom Karis behov for ivaretakende kommunikasjon. 


\section{三 «Hun reagerte også sterkt på at legen omtalte barnet som tilhørende til 'en menneskegruppe', i motsetning til å være et likestilt og verdig menneske.»}

I likhet med Karis opplevelse fortalte Åse om situasjonen da legen formidlet at datteren hennes hadde Downs syndrom:

«... så sa han [legen]: 'Jeg hører rykter om at dere mistenker at han har Downs syndrom, og vi er ikke i tvil om det'. 'Wææææ', der satt vi, mannen min gikk bare ned for telling ..., og så snur han seg til pappaen og spør om han har noen kunnskap om denne menneskegruppen. 'Ehhhh', svarte pappaen .... Da sa legen at det var muligheter for dem da, og så god tur. Og da liksom å bli dyttet ut fra det legekontoret, etter å ha fått den beskjeden, var rett og slett et slag rett i trynet.»

Åse beskrev at opplevelsen av å motta beskjeden om at sønnen hadde Downs syndrom fra legen, var preget av legens mangel på forståelse for deres følelsesmessige og kommunikative behov. Hun fortalte at beskjeden ble gitt på en svært lite empatisk måte, og at hun og faren ble sjokkerte, både over budskapet og måten det ble formidlet på.

Åse beskrev tydelig opplevelsen av ikke å bli sett som «menneske med følelser» når det gjaldt behovet for en varsom og sensitiv formidling av budskapet. Hun beskrev reaksjonen hun og mannen hadde på dette («slag i trynet», «å bli dyttet ut av legekontoret»). Hun reagerte også sterkt på at legen omtalte barnet som tilhørende til «en menneskegruppe», i motsetning til å være et likestilt og verdig menneske.

\section{Å være et medmenneske}


I sterk kontrast til foreldrenes beskrivelse av å føle seg som «mindre enn et helt menneske», opplevde flere av deltakerne i studien å få mulighet til å være et medmenneske i møte med helsepersonellet. De opplevde både at dem selv og barnet ble behandlet som medmennesker, og at helsepersonellet posisjonerte seg selv på en måte som gjorde dem til likeverdige medmennesker. I dette hovednarrativet beskrev deltakerne opplevelser hvor de ble møtt med empati og ydmykhet. De beskrev at helsepersonellet tok seg tid, og at de fikk emosjonell omsorg og støtte.

\section{Lavmælte og vennlige sykepleiere}

Som nevnt tidligere fortalte Kari at hun hadde opplevd å føle seg forlatt av jordmoren på fødeavdelingen, og at legen på barselavdelingen ikke så hennes behov. Men Kari hadde også hatt en positiv opplevelse i møte med sykepleierne på intensivavdelingen:

«De spurte: 'Likner hun på noen i familien deres?' 'Neeei', sa vi da .... De var så søte og vennlige - de var veldig konkrete, men veldig lavmælte og vennlige. Og da sa de: 'Vi tror hun har Downs syndrom, og det tror vi fordi ...', og så viste de oss det: på grunn av ørene, på grunn av tærne. 'Vi tror det på grunn av linjer som mangler i hendene', på grunn av sånn og sånn.»

\section{«Sykepleieren ga Åses mann tid og rom til å uttrykke seg og snakke om sin opplevelse av situasjonen alene med henne.»}


Kari beskrev en interaksjon der sykepleierne kommuniserte på en varsom og ivaretakende måte, «lavmælte og vennlige». Da de leverte budskapet om at de mistenkte at datteren hadde Downs syndrom, forklarte de helt konkret begrunnelsen for dette ved at de viste foreldrene barnets ører og tær. Her kommuniserte sykepleierne at barnet var et medmenneske og sannsynligvis liknet sine foreldre, som alle andre barn. Det står i sterk kontrast til legen som spurte mannen til Åse om han hadde kjennskap til «denne menneskegruppen».

Åse beskrev at hun opplevde å bli møtt på en god måte av en sykepleier på barselavdelingen. Hendelsen sto i motsetning til beskrivelsen av opplevelsen Åse og mannen hadde da en lege fortalte at barnet deres hadde Downs syndrom:

«Hun [sykepleieren] sa hun trengte å prate med han, og de hadde en lang samtale, uten meg til stede.»

Åse fortalte at mannen hennes fikk en sterk reaksjon, og at sykepleieren så hans behov for omsorg og støttende kommunikasjon. Sykepleieren ga Åses mann tid og rom til å uttrykke seg og snakke om sin opplevelse av situasjonen alene med henne.

I denne interaksjonen opplevde både Åse og mannen hennes at sykepleieren var et medmenneske. Samtidig tilrettela sykepleieren for at faren kunne oppleve seg selv som et menneske med en naturlig og forståelig reaksjon da han fikk beskjed om at det nyfødte barnet hadde Downs syndrom.

\section{Diskusjon}


Internasjonal forskning viser at foreldre til barn med Downs syndrom får lite oppfølging av følelsesmessige behov, og erfarer på ulike tidspunkter av barnets oppvekst at helsepersonell kommuniserer på en måte som oppleves som belastende (7-9, 16, 17). Disse funnene er i tråd med det foreldrene i studien vår fortalte om opplevelsen av fødselen og tiden umiddelbart etter på sykehuset.

Foreldrene hadde i så måte flere konkrete erfaringer i møte med helsepersonell der de opplevde at dem selv og barnet var mindre enn «et helt menneske». Det «hele mennesket» kan forstås som mennesket som i første omgang har fått et barn med en helseutfordring som skal ivaretas, men som også har behov for at egne bekymringer og følelser blir ivaretatt. Disse aspektene inngår i foreldres helhetlige helsebilde, som skapes i møtet med de helseprofesjonelle (18).

\section{Viktig å føle aksept}

Når foreldre har ventet på og gledet seg til å få et funksjonsfriskt barn, kan deres følelsesmessige reaksjon være sterkt preget av sjokk, sorg og sinne.

Det kan være utfordrende å håndtere egne følelser og samtidig kommunisere med og respondere følelsesmessig til barnet sitt (5). Det er derfor rimelig å anta at det kan bidra på en positiv måte til familiens videre fungering og livskvalitet når foreldrene opplever å bli møtt av helsepersonell på en måte som ivaretar deres behov for å bli sett som «et helt menneske» eller «et menneske med følelser».

For eksempel er det mulig at når foreldrene har konkrete opplevelser av aksept og anerkjennelse i relasjonen med helsepersonellet, kan det bidra til godt samspill mellom foreldre og barn. Det kan dessuten danne et godt utgangspunkt for den relasjonen som skal skapes over tid mellom hovedomsorgsgiverne og barnet (4). I så måte kan ivaretakende kommunikasjon med helsepersonellet bidra til at foreldre kan konstruere og formidle positive fortellinger om barnet fra fødselen og sykehuset. 
Slike fortellinger kan ha stor følelsesmessig betydning og kan fungere som motbør til opplevelsen av sosialt stigma i hverdagen når familien har kommet hjem fra sykehuset (16). I tråd med dette hadde noen foreldre opplevelser med at helsepersonell omtalte barnet deres på en måte som likestilte barnet som medmenneske, og der de selv opplevde å bli anerkjent som medmenneske, noe som hadde stor betydning for foreldrene i denne studien.

Når det gjelder en slik medmenneskelig tilnærming, kan ifølge Anderson (19) «withness» være en måte å kommunisere med det andre mennesket på, som gjør det mulig for vedkommende å føle seg ivaretatt. Hun beskriver helsepersonellets tilnærming som å «snakke med», «handle med» og «respondere med» den personen som trenger bistand (19).

\section{Sosialt stigma}

Forskning viser at foreldre til barn med funksjonsnedsettelser opplever «annerledeshet» og stigma i den sosiale konteksten $(16,17,20,21)$. Dermed kan det være spesielt viktig i en tidlig fase av foreldreskapet at helsepersonellet er «sammen med» foreldrene når de har sin første reaksjon og tidlige opplevelse.

I det øyeblikket foreldre får vite at deres barn har Downs syndrom, og i tiden umiddelbart etter, er helsepersonellets kommunikasjon viktig for at foreldrene skal mestre den følelsesmessige belastningen de opplever der og da. I tillegg kan opplevelsen av at dem selv og barnet blir anerkjent og ivaretatt, danne et positivt utgangspunkt for den videre tilknytningen og samspillet som skal skapes mellom foreldre og barnet over tid (4).

\section{Studiens svakheter}


Vi rekrutterte utvalget fra Ups \& Downs-foreninger, og det er mulig at de foreldrene som meldte seg frivillig, hadde hatt spesielt vanskelige opplevelser. Studien kunne i så måte vært styrket av et større utvalg og flere beskrivelser av foreldres konkrete erfaringer, men tidsbegrensning gjorde at det ikke var mulig. I kontekst av en narrativ tilnærming kunne det også vært ønskelig å intervjue deltakerne flere ganger over tid, spesielt med tanke på å utforske hvilken langsiktig betydning det tidlige møtet og kommunikasjonen med helsepersonellet har for familien og barnet.

\section{Konklusjon}

Med denne studien ønsket vi å formidle kunnskap om foreldres konkrete levde erfaringer fra sykehuset ved fødselen og tiden umiddelbart etter å ha fått et barn med Downs syndrom. Slik synliggjør studien helsepersonellets sentrale rolle og potensial overfor foreldres følelsesmessige behov og samspill med barnet i denne tidlige fasen av foreldreskapet.

Studien indikerer at det å tilrettelegge for en kommunikasjon som får foreldre til å føle at dem selv og barnet er «medmennesker», kan være en viktig ressurs for å ivareta foreldres følelsesmessige reaksjoner på sykehuset i tiden etter fødselen.

Det er også rimelig å anta at helsepersonell ved hjelp av anerkjennende og ivaretagende kommunikasjon bidrar til å tilrettelegge videre for den relasjonen og samspillet som skal skapes mellom foreldrene og barnet over tid.

\section{Referanser}

1. Howe D. Disabled children, maltreatment and attachment. British Journal of Social Work.

2006;36:743-60. 
2. van IJzendoorn MH, Goldberg S, Kroonenberg PM, Frenkel OJ. The relative effects of maternal and child problems on the quality of attachment: A metaanalysis of attachment in clinical samples. Child Development. 1992;63:840-58.

3. Gundersen T, Farstad GR, Solberg A. Ansvarsfordeling til barns beste? Barn og unge med funksjonsnedsettelser i barnevernet. Oslo: NOVA, Norsk institutt for forskning om oppvekst, velferd og aldring; 2011. Rapport 17/2011.

4. Lewis V. Development and disability. 2. utg. Storbritannia: Blackwell Publishing; 2003.

5. Grue L. Hinderløype: Foreldre, barn og funksjonshemning. Oslo: NOVA, Norsk institutt for forskning om oppvekst, velferd og aldring; 2011.

6. Moser I. Against normalisation: subverting norms of ability and disability. Science as Culture. 2000;9:201-40.

7. Skotko B. Mothers of children with Down syndrome reflect on their postnatal support. Pediatrics. 2005;115:64-77.

8. Hedov G, Wikblad K, Anneren G. First information and support provided to parents of children with Down syndrome in Sweden: clinical goals and parental experiences. Acta Pædiatrica. 2008;91:1344-9.

9. Lundeby H, Tøssebro J. Exploring the experiences of «not being listened to» from the perspective of parents with disabled children. Scandinavian Journal of Disability Research. 2008;10:258-74.

10. Cromby J, Harper D, Reavey P. Psychology, mental health and distress. Hampshire: Palgrave Macmillan; 2013. 
11. Merleau-Ponty M. Phenomenology of perception. London: Routledge; 2002.

12. Del Busso L, Reavey P. Moving beyond the surface: poststructuralist phenomenological research on young women's embodied experiences in everyday life. Psychology \& Sexuality. 2013;4:46-61.

13. Del Busso L. Being-in-motion: movement, femininity and space in young women's narratives of their embodied experiences in everyday life. (Doktoravhandling.) London: London South Bank University; 2009.

14. Langdridge D. Phenomenological psychology: theory, research and method. UK: Pearson Education Limited; 2007.

15. Ramazanoglu C, Holland J. Feminist methodology: challenges and choices. London: Sage; 2002.

16. Berg B, Strøm A. Foreldregrupper når barnet har store funksjonsnedsettelser. Sykepleien Forskning. 2012;7:350-5. DOI: 10.4220/sykepleienf.2012.0153.

17.. Berg B, Strøm A. Et annerledes og ensomt foreldreskap: en kvalitativ studie av foreldre til barn som har funksjonsnedsettelser og deres utfordringer $\mathrm{i}$ møte med sine uformelle sosiale nettverk. Fontene forskning. 2012;1:56-68.

18. Leonardsen AL, Del Busso L, Grøndahl VA, Jelsness-Jørgensen L. «It’s a whole human being»: A qualitative study of care experiences among patients treated in decentralised healthcare services. European Journal for Person Centered Healthcare. 2017;5:82-7.

19. Anderson H. Collaborative Practice: A way of being «with». Psychotherapy and Politics International. 2012;10(2):130-45. 
20. Green SE. «What do you mean 'what's wrong with her?'»: stigma and the lives of families of children with disabilities. Social Science \& Medicine. 2003;57:1361-74.

21. Borg E. Holdninger til funksjonshemmede i Norge 1999-2005. Oslo: Norsk institutt for forskning om oppvekst, velferd og aldring; 2008. 